\title{
The Grammatical Function \\ of Papiamentu Tone
}

\author{
SILVIA KOUWENBERG
}

\begin{abstract}
I propose that tone in Papiamentu is a marker of the morphosyntactic category of a given form. Its primary function, therefore, is grammatical. This account of Papiamentu tone differs from previously proposed accounts, which treat tone in Papiamentu as a lexical property (Römer, 1991; Rivera-Castillo, 1998) or as a purely phonological property (Devonish \& Murray, 1995).
\end{abstract}

\section{Introduction}

Römer (1977, subsequent work) has drawn attention to the relevance of tone in Papiamentu (Pp), with pairs such as mata 'to kill' (LH melody) and mata 'plant' (HL melody) distinguishable by tone melody only. ${ }^{1}$ Joubert (1991:323-330) lists 250 more pairs of bisyllabic vowel-final words which contrast only in tone melody. In each case, one member of the pair combines penultimate stress with a LH melody, the other with a HL melody. There are, however, several facts which militate against locating the differences between the semantic and morphosyntactic properties of words such as mata 'to kill' and mata 'plant' in the different associations between a tone melody and the segmental string.

\footnotetext{
${ }^{1}$ This paper discusses the tone and stress properties of Pp content words. The tone and stress properties of closed class functional items is not the subject of this paper. See Römer (1977, subsequent work), Kouwenberg \& Murray (1994) for a consideration of these. This paper is also not concerned with the phonetic implementation of tone. For instance, the realization of a phonological $\mathrm{L}$ tone as a phonetic fall in stressed positions, as in the first syllable of mata 'to kill' (LH), is of no relevance to this paper. I wish to thank Darlene LaCharité, Maarten Mous and Norval Smith, who commented on earlier versions of this paper.
} 
First, similar contrasts are not found for monosyllabic content words, for words of more than two syllables length, or for bisyllabic words which end in a closed syllable. These systematic gaps in the data can be considered suspicious. After all, languages which employ tone contrastively for bisyllabic words, typically also do so for monosyllabic words and longer words.

Second, the strong correlation of tone melody with class membership is suspect. Thus, all except 37 of the 250 contrasting bisyllabic pairs are verb (LH) / noun (HL) pairs.

A third property which raises doubts about the nature of $\mathrm{Pp}$ tone is that, normally, there is either (i) only a single high tone in a word, which coincides with main stress, except predictably in bisyllabic vowel-final verbs such as mata 'to kill', where penultimate stress is combined with a final high tone, or (ii) high tones occur on alternating syllables.

These properties of Pp tone suggest that it should not be treated as a primitive in Pp phonology, as was done in Römer (1991) and Rivera-Castillo (1998), whose models require a lexical specification for tone. If tone were lexical, we would expect its combination with the segmental string to signal a unique lexical item with its associated semantic and grammatical properties. The actual situation is the opposite, where the grammatical properties of the Pp forms predict the tone melody, as is clearly seen in the bisyllabic verb / noun pairs.

In the following, I will first set out the basic facts of tone and stress placement in Pp in some more detail. I will then turn to a consideration of the accounts of Pp tone proposed by previous authors. Finally, I will present an alternative account, which takes Pp tone to be a signal of morphosyntactic category. I will extend this analysis to derived forms.

\section{Regular tone and stress placement}

Seeing that a high tone normally coincides with stress in Pp content words, tone and stress are either equally predictable or equally unpredictable. Traditionally, stress placement in Pp has been assumed to conform to a Spanish pattern. This means that $\mathrm{Pp}$, like Spanish, is expected to place stress on the penultimate syllable in words ending in a vowel or $/ 1, \mathrm{r}, \mathrm{n} /$, on the final syllable in words ending in another consonant or a diphthong (see, for instance, Joubert, 1991:xiii). Pp spelling conventions reflect this, with an acute used to mark stress where these assumptions fail to predict its location.

Unfortunately, these spelling conventions confer exceptional status on all Pp verbs three or more syllables long, which all end in a stress-bearing open syllable, as for instance in risibi 'to receive', aparesé 'to appear', and ekiboká 'to make a mistake' - each carrying an acute marking stress on the final syllable. The fully predictable nature of high tone and stress placement in verbs is further seen where prefixes such as re-, des- create trisyllabic verbs from bisyllabic verb bases, as in boltia 'to turn over' > reboltiá 'to upset', hasi 'to 
do' > deshasí 'to undo'. In each case, the bisyllabic verb base combines penultimate stress with a LH melody, whereas the trisyllabic derived verb has a final stressed and high-toned syllable, as expected of verbs of that length.

The facts are rather different for nouns, adjectives, and adverbs, which seem to follow the Spanish pattern more closely. However, in considering Pp words which end in /l,r,n/, there are easily as many with penultimate stress, as with final stress (Kouwenberg \& Murray, 1994:14). A consideration of the vowel in the final syllable reveals the source of this difference. Where stress is penultimate, as for instance in binager 'vinegar' and òrgel 'organ', the final syllable, without exception, contains [ə], represented orthographically as "e". In contrast, where stress is final, as in fabor 'favour', and ospital 'hospital', the final syllable contains a full vowel. The different stress placement in these forms can be accounted for if we accept that the final syllables of binager and orgel contain a single mora, $/ \mathrm{r} /$ and $/ 1 /$, respectively, whereas the final syllables of fabor and ospital contain two moras, /or/ and /al/, respectively. The stress placement facts follow straightforwardly from a recognition that in nouns, adjectives, and adverbs, stress placement is sensitive to the weight of the final syllable. ${ }^{2}$

Thus, the net result of assuming a Spanish-type stress system for Pp is that trisyllabic and longer verbs, with a fully predictable stress location, are treated as an open-ended class of exceptions, and that the quantity sensitivity of stress placement in nouns, adjectives and adverbs is overlooked. This is a clear illustration of the type of misrepresentation which may result from an approach which takes as its terms of reference the grammatical categories of a lexical source language rather than those of the Creole language itself.

The regular patterns for high tone and stress placement in polysyllabic content words are summarized in Table 1. Monosyllabic content words, which consist of a single accented and high-toned syllable, are not considered. ${ }^{3}$

\footnotetext{
${ }^{2}$ A clear indication of the relevance of quantity sensitivity in Pp phonology can further be seen in the requirement that the minimal content word is bimoraic, i.e. contains at least a branching rhyme if monosyllabic (see Kouwenberg \& Murray, 1994:12). Thus, every content word is at least a foot.

${ }^{3}$ Here and in the following, using the conventions established in Römer's work, lines under and over vowels indicate low and high tones, respectively. Diacritics are used according to the conventions of Pp orthography as accepted in Curaçao and Bonaire: an acute marks stress where it does not conform to the conventions of Spanish stress assignment, a grave accent distinguishes vowel quality, as does a macron. Devonish \& Murray (1995), while also employing underlines and other diacritics, use these in a rather different manner. The representations in this article are quite dissimilar from theirs, therefore.
} 
Table 1. Regular tone and stress placement (after Kouwenberg \& Murray, 1994:12)

\begin{tabular}{|c|c|c|c|}
\hline \multicolumn{2}{|c|}{ POLYSYLLABIC VERBS } & \multicolumn{2}{|c|}{$\begin{array}{l}\text { POLYSYLLABIC NOUNS, ADJECTIVES, } \\
\text { ADVERBS }\end{array}$} \\
\hline Bisyllabic & longer & final syllable heavy & final syllable light \\
\hline $\begin{array}{l}\text { final } \mathrm{H} \text {, } \\
\text { penultimate } \\
\text { stress }\end{array}$ & $\begin{array}{l}\text { final } \mathrm{H}, \\
\text { final stress }\end{array}$ & $\begin{array}{l}\text { final } \mathrm{H} \text {, } \\
\text { final stress }\end{array}$ & $\begin{array}{l}\text { penultimate } \mathrm{H}, \\
\text { penultimate stress }\end{array}$ \\
\hline $\begin{array}{l}\text { kaskkā 'to peel' } \\
\text { matā 'to kill' } \\
\text { bulāa 'to jump' }\end{array}$ & $\begin{array}{l}\text { kūminsầ 'to } \\
\text { begin' } \\
\text { âtakầ 'to attack' } \\
\text { kōmpréndê 'to } \\
\text { understand' }\end{array}$ & $\begin{array}{l}\text { falīs 'suitcase' } \\
\text { matrōs 'sailor' } \\
\text { ōspitāl 'hospital' }\end{array}$ & 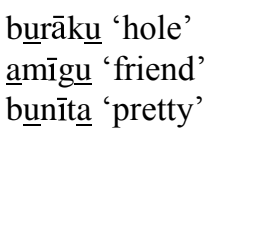 \\
\hline
\end{tabular}

As seen in Table 1, verbs unexceptionally locate a high tone on the final syllable, but show variation in the location of stress, which is sensitive to the length of the verb. It is further seen that polysyllabic nouns, adjectives and adverbs behave differently from verbs in several respects: the location of a high tone is not fixed, the location of a high tone and stress coincide, and their location can be predicted from the weight of the final syllable.

We further note that high and low tones alternate, i.e. there is a preference for adjacent syllables to carry non-identical tones. On words of sufficient length, such as kuminsá 'to begin', ospital 'hospital', this results in several high tones in the surface melody.

\section{Irregular tone and stress placement}

A small number of bisyllabic nouns (mango 'mango' etc.) display non-coincidence of stress and high tone, stress occuring on the penultimate syllable as expected of nouns ending in a light syllable, but high tone occuring on the final syllable.

Also, several nouns and adjectives occur with an irregular tone and stress pattern as a result of a historical development which saw the suppression of a final syllable in these Iberian-derived forms (e.g. piská 'fish'; cf. Spanish pescado), or of a final consonant (e.g. muhé 'woman'; cf. Spanish mujer). In addition, several forms have inherited the irregular tone and stress placement of their etymological source (e.g. ágila 'needle', difísil 'difficult').

Finally, high tones on adjacent syllables, as in bistek 'steak', harspèl 'hairclip', reflects the compound status of the non-Iberian etymological source forms of these words.

\footnotetext{
${ }^{4}$ Alternating "secondary" high tones are optional, present in the speech of some individuals, absent in that of others.
} 
Among verbs, exceptional patterns are found only among a small number of bisyllabic verbs (sunchi 'to kiss' etc.) - invariably of non-Iberian (Dutch or English) etymology. These show exceptional coincidence of stress and high tone on a final syllable.

The patterns of irregular tone and stress placement are summarized in Table 2.

Table 2. Irregular tone and stress placement

\begin{tabular}{|c|c|}
\hline Nouns and Adjectives & \\
\hline $\begin{array}{l}\text { regular penultimate stress, but } \mathrm{H} \text { on } \\
\text { a final light syllable }\end{array}$ & $\begin{array}{l}\text { mangō 'mango', muchā 'child', tambē } \\
\text { 'also' }\end{array}$ \\
\hline stress and $\mathrm{H}$ on a final light syllable & $\begin{array}{l}\text { piská 'fish', lihè 'fast, light', āwasă } \\
\text { (name of square) }\end{array}$ \\
\hline $\begin{array}{l}\text { antepenultimate stress and } \mathrm{H} \\
\text { instead of penultimate }\end{array}$ & $\begin{array}{l}\text { ăgilā 'eagle', răpidōo 'fast', dẹpósitōo } \\
\text { 'warehouse' }\end{array}$ \\
\hline $\begin{array}{l}\text { penultimate stress and } \mathrm{H} \text { ignores a } \\
\text { final heavy syllable }\end{array}$ & dịfîsil 'difficult', mărtịr 'martyr' \\
\hline $\begin{array}{l}\text { regular main stress and } \mathrm{H} \text {, but } \\
\text { additional } \mathrm{H} \text { on adjacent syllables }\end{array}$ & $\begin{array}{l}\text { bīstēk 'steak', hārspēl 'hairclip', } \\
\text { tēblāchi '(serving) tray' }\end{array}$ \\
\hline \multicolumn{2}{|l|}{ Verbs } \\
\hline $\begin{array}{l}\text { regular penultimate stress, but } \\
\text { penultimate instead of final } \mathrm{H}\end{array}$ & $\begin{array}{l}\text { sūnchi 'to kiss', skēiru 'to brush', } \\
\text { wèlderr 'to weld' }\end{array}$ \\
\hline
\end{tabular}

\section{Previous models}

We turn now to the accounts given by previous authors of the facts surveyed in the preceding before considering an alternative account.

Römer's (1991) analysis of Pp tone relies on the identification of an anchoring syllable for a tone melody, followed by the application of rules which establish the associations between that tone melody and the segmental string. As an example, consider his derivation of a sample of polysyllabic words in Table 3. The accented vowel, identified in the representation as a starred vowel,

\footnotetext{
${ }^{5}$ In some cases, the final syllable of verbs displaying this pattern contain $[{ } \mathrm{C}]$ in the rhyme, e.g. wèlder 'to weld'. Recall that this sequence is considered monomoraic, underlyingly.
} 
is an anchor for the rightmost high tone in what is proposed to be the underlying tone melody. The derivation involves a sequence of steps: Initial Tone Assocation (ITA) anchors the rightmost $\mathrm{H}$ in the melody to the accented vowel, followed by Leftward Tone Association (LwTA), Tone Shift (TS), and Sentence Low Association (SLA) or Residual Tone Association (RTA).

Forms which occur with an irregular tone and stress pattern - according to the conventions established in the preceding sections - are placed in shaded cells.

Table 3. Derivation of Pp words, after Römer (1991: 45-48)

\begin{tabular}{|c|c|c|c|c|c|}
\hline INPUT & $\begin{array}{l}\mathrm{S} * \mathrm{a} \mathrm{k} \mathrm{u} \\
\mathrm{H} \mathrm{L}\end{array}$ & $\begin{array}{l}\mathrm{m} * \mathrm{a} n \mathrm{go} \\
\mathrm{LHL}\end{array}$ & $\begin{array}{l}\text { matr }{ }^{*} \text { o s } \\
\text { L H L }\end{array}$ & $\begin{array}{l}\text { a t a k*a } \\
\mathrm{L} \mathrm{H} \mathrm{L}\end{array}$ & $\begin{array}{c}\text { a w a s *a } \\
\text { HL H L }\end{array}$ \\
\hline ITA & $\begin{array}{c}\mathrm{s} * \mathrm{a} \mathrm{k} \mathrm{u} \\
\vdots \\
\mathrm{H} \mathrm{L}\end{array}$ & $\begin{array}{c}\mathrm{m} * \mathrm{a} \mathrm{ng} \mathrm{o} \\
\vdots \\
\mathrm{L} H \mathrm{~L}\end{array}$ & $\begin{array}{c}\mathrm{mat}{ }^{*} \mathrm{os} \\
\vdots \\
\mathrm{LH} \mathrm{L}\end{array}$ & $\begin{array}{r}\text { a t a k } * \text { a } \\
\vdots \\
\mathrm{L} \mathrm{H} \mathrm{L}\end{array}$ & $\begin{array}{r}\text { a w a s } * \mathrm{a} \\
\vdots \\
\mathrm{HLHL}\end{array}$ \\
\hline LWTA & $\left.\right|_{\mathrm{H} \mathrm{L}} ^{\mathrm{s}}{ }_{\mathrm{a} \mathrm{k} \mathrm{u}}$ & $\begin{array}{c}\mathrm{m} * \mathrm{a} \text { n } \mathrm{o} \\
\vdots \backslash \\
\mathrm{L} \mathrm{H} \mathrm{L}\end{array}$ & $\begin{array}{c}\mathrm{matr} * \mathrm{os} \\
\ddots \\
\mathrm{LH} \mathrm{L}\end{array}$ & 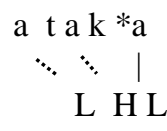 & $\begin{array}{c}\text { a w a s *a } \\
\vdots \quad \vdots \quad \mid \\
\text { H L H L }\end{array}$ \\
\hline TS & N.A. & $\begin{array}{c}\mathrm{m} * \mathrm{a} \text { g o } \\
\mid \neq \quad \vdots \\
\mathrm{L} \text { H L }\end{array}$ & N.A. & N.A. & N.A. \\
\hline $\begin{array}{l}\text { SLA, } \\
\text { RTA }\end{array}$ & $\begin{array}{c}\mathrm{s} * \mathrm{k} \mathrm{u} \\
\backslash \quad \vdots \\
\mathrm{H} \mathrm{L}\end{array}$ & $\begin{array}{c}\mathrm{m} * \mathrm{n} \text { g o } \\
\mid \begin{array}{r}1 \\
\mathrm{~L}\end{array} \\
\mathrm{H} \mathrm{L}\end{array}$ & $\begin{array}{c}\mathrm{matr} * \mathrm{os} \\
\backslash \mid \ddots \\
\mathrm{LHL}\end{array}$ & $\begin{array}{l}\text { at a k *a } \\
\backslash \backslash \mid \ddots \\
\mathrm{L} H \mathrm{~L}\end{array}$ & $\begin{array}{c}\text { a w a s *a } \\
\backslash|| \bullet \\
\text { H L H L }\end{array}$ \\
\hline OUTPUT & $\begin{array}{l}\mathrm{s} \overline{\mathrm{a}} \mathrm{k} \underline{\mathrm{u}} \\
\text { 'bag' }\end{array}$ & $\begin{array}{l}\mathrm{m} \text { a } \mathrm{n} \mathrm{g} \overline{\mathrm{o}} \\
\text { 'mango' }\end{array}$ & $\begin{array}{l}\mathrm{m} \underline{\mathrm{a}} \mathrm{t} \mathrm{r} \overline{\mathrm{o}} \mathrm{s} \\
\text { 'sailor' }\end{array}$ & $\begin{array}{l}\underline{\mathrm{a}} \mathrm{t} \underline{\mathrm{a}} \mathrm{k} \text { à } \\
\text { 'to attack' }\end{array}$ & $\begin{array}{l}\overline{\mathrm{a}} \mathrm{w} \text { a s à } \\
\text { (name of a } \\
\text { town square) }\end{array}$ \\
\hline
\end{tabular}

Several problems can be noted for Römer's model. First, the method whereby the accented syllable is identified is unclear. Nowhere does he address this problem explicitly, but he assumes a Spanish-type system of accentuation throughout his published work. As seen in the preceding, this means that trisyllabic and longer verbs are treated as lexical exceptions, which are thus required to carry - in addition to information about the segmental string of which they are composed and the semantic properties associated with that segmental string - a prosodic mark which identifies the accented syllable. Apart from this, the model involves no less than four different tone melodies, HL, LHL, HLHL, LHLHL, for which lexical selection has to be invoked, further increasing the amount and complexity of the information provided in the lexicon. The intricacy of this model is also seen in the application of rules of delinking and relinking (ITS. LwTA, etc.) which mediate between the underlying and the surface melody. A related problem is the fact that the derivation of 
regular and irregular melodies is equally intricate, though we normally expect less complexity where a default or predictable representation is derived. For instance, the derivation of awasá, a noun with an irregular tone and stress pattern, is identical to the derivation of ataká, a verb with a regular tone and stress pattern.

In short, the model involves considerable cost, both in terms of the acquisition of the system and in terms of the information stored in the lexicon. The Pp tonal system is far too simple to warrant a model of such complexity.

Rivera-Castillo (1998) proposed a rather different treatment of Pp tone and stress, in the form of a system of parsing constraints which identify the (bisyllabic) foot as the organisational unit where both stress and tone are located, limiting the number of stressed syllables and the number of high tones within a foot to one each. Furthermore, she postulates constraints which make stress assignment at least partially dependent on tone. Some examples are provided in Table 4.

Table 4. Distribution of tone and stress in Pp words, after Rivera-Castillo (1998)

\begin{tabular}{|l|l|l|}
\hline Word & $\begin{array}{l}\text { prosodic } \\
\text { structure }\end{array}$ & tone and stress placement \\
\hline $\begin{array}{l}\mathrm{m} \overline{\mathrm{a}} \mathrm{t} \underline{\mathrm{a}} \\
\text { plant' }\end{array}$ & $\begin{array}{l}\text { two syllables }= \\
\text { one foot }=\text { word }\end{array}$ & $\begin{array}{l}\text { a single high tone on the initial syllable } \\
\text { of the foot is a predictor for stress on } \\
\text { that syllable }\end{array}$ \\
\hline $\begin{array}{l}\mathrm{m} \underline{\mathrm{a}} \mathrm{t} \overline{\mathrm{a}} \\
\text { to kill' }\end{array}$ & $\begin{array}{l}\text { two syllables }= \\
\text { one foot }=\text { word }\end{array}$ & $\begin{array}{l}\text { a single high tone on the final syllable } \\
\text { of the foot; a single stress on the initial } \\
\text { syllable of the foot }\end{array}$ \\
\hline $\begin{array}{l}\mathrm{m} \underline{\mathrm{a}} \mathrm{t} \mathrm{a} \\
\text { 'killed' } \\
\text { (participle) }\end{array}$ & $\begin{array}{l}\text { two syllables }= \\
\text { one foot }=\text { word }\end{array}$ & $\begin{array}{l}\text { a single high tone on the final syllable } \\
\text { of the foot; a single stress on the same } \\
\text { syllable }\end{array}$ \\
\hline $\begin{array}{l}\text { ch } \underline{\mathrm{u}} \mathrm{k} \underline{\mathrm{u}} \text { la } \mathrm{t} \mathrm{t} \underline{\mathrm{i}} \\
\text { chocolate' }\end{array}$ & $\begin{array}{l}\text { (two syllables }= \\
\text { one foot) }+(\mathrm{two} \\
\text { syllables }=\text { one } \\
\text { foot }=\text { word }\end{array}$ & $\begin{array}{l}\text { initial foot contains low toned syllables } \\
\text { only, hence no stress; second foot con- } \\
\text { tains high tone on the initial syllable, } \\
\text { hence stress also on that syllable }\end{array}$ \\
\hline
\end{tabular}

With the surface melody following from the location of a single high tone in a foot and the default assignment of low tones, RC's model has the advantage that it does not require reference to underlying tone melodies. She does not, however, determine how the location of a high tone may be predicted. Her account thus runs up against the same problem as Römer's model: it requires lexical marking of the location of a high tone. In addition, while Rivera-Castillo's model predicts the presence of stress on the initial syllable of mata 'plant' from the location of a high tone on that syllable, there is no predictor for the location of stress in mata 'to kill', and matá 'killed' - the 
latter a derived form, which she treats on par with underived forms. The system, in other words, underdetermines the data. Even more serious in this respect is her failure to take into account verbs more than two syllables long, which place stress in a different position from shorter verbs, and words with irregular tone and stress placement patterns(hence no shaded cells in Table 4) - data which, surely, must be considered relevant.

Devonish \& Murray's (1995) account of Pp tone and stress placement takes tone and stress, as well as vowel length and full intensity of vowels, to be possible implementations of phonological prominence. The construction of right-headed maximally binary feet from the right edge of the word - possibly ignoring an extrametrical syllable at the right edge - results in the identification of prominent syllables, with high tone, stress, etc. as implementations of this prominence. Bimoraic syllables possess inherent prominence. It follows that such heavy syllables will naturally attract additional marks of prominence such as high tone and stress. Their model further distinguishes between words for which either inherent prominence or prominence assigned by foot construction accounts for the resulting tone melody, and words which require a lexically assigned HL melody with some additional machinery to derive the surface melody. Table 5 illustrates all this; shaded cells contain irregular forms.

Table 5. Derivation of Pp words, after Devonish \& Murray (1995:49ff)

\begin{tabular}{|c|c|c|}
\hline $\begin{array}{l}\mathrm{p} \text { i s k à } \\
\text { 'fish' }\end{array}$ & $\begin{array}{l}\text { right-headed foot assigns prominence } \\
\text { to rightmost syllable }\end{array}$ & $\begin{array}{l}\text { predictable LH } \\
\text { melody }\end{array}$ \\
\hline $\begin{array}{l}\mathrm{p} \overline{\mathrm{a}} \mathrm{p} \underline{\mathrm{a}} \\
\text { 'Pope' }\end{array}$ & $\begin{array}{l}\text { final syllable is extrametrical, } \\
\text { penultimate syllabe heads a foot, } \\
\text { hence is prominent }\end{array}$ & $\begin{array}{l}\text { predictable } \mathrm{HL} \\
\text { melody }\end{array}$ \\
\hline $\begin{array}{l}\text { b ìs t ē k } \\
\text { 'steak' }\end{array}$ & $\begin{array}{l}\text { both syllables bimoraic, hence both } \\
\text { syllables inherently prominent }\end{array}$ & $\begin{array}{l}\text { predictable } \mathrm{HH} \\
\text { melody }\end{array}$ \\
\hline $\begin{array}{l}\mathrm{b} \underline{\mathrm{u}} \mathrm{n} \overline{1} \mathrm{t}, \underline{\mathrm{a}} \\
\text { 'pretty' }\end{array}$ & $\begin{array}{l}\text { rightmost syllable extrametrical, } \\
\text { preceded by right-headed foot, which } \\
\text { assigns prominence to penultimate } \\
\text { syllable }\end{array}$ & $\begin{array}{l}\text { predictable } \\
\text { LHL melody }\end{array}$ \\
\hline $\begin{array}{l}\mathrm{b} \underline{\mathrm{u}} 1 \overline{\mathrm{a}} \\
\text { 'to jump' }\end{array}$ & $\begin{array}{l}\text { both syllables are marked as } \\
\text { prominent; HL melody is lexically } \\
\text { assigned }\end{array}$ & $\begin{array}{l}\text { resulting } \\
\text { melody is } \overparen{\mathrm{HL}} \mathrm{H}\end{array}$ \\
\hline $\begin{array}{l}\mathrm{k} \text { o } \mathrm{m} \text { p r e n d è } \\
\text { 'to understand' }\end{array}$ & $\begin{array}{l}\text { right-headed feet constructed from } \\
\text { right edge; HL melody is lexically } \\
\text { assigned }\end{array}$ & $\begin{array}{l}\text { resulting } \\
\text { melody } \\
\text { HLLH }\end{array}$ \\
\hline
\end{tabular}

Devonish \& Murray's claim that stress and high tone implement prominence has the advantage of providing a straightforward account for the fact 
that stress and high tone generally occur on the same syllable. However, like Römer and Rivera-Castillo, they rely heavily on lexical specification, even for items which are perfectly predictable. Thus, papa 'Pope' (mistranslated in Devonish \& Murray as 'father') and bunita 'pretty' are representative of an open-ended class of nouns and adjectives which all show identical, fully predictable behavior. Devonish \& Murray's model requires a lexical representation of these forms which marks the final syllable as extrametrical, $p a\{p a\}$ and $b u . n i\{t a\}$, respectively, thus suggesting unpredictability. Similarly, bula 'to jump' is representative of a pattern of prominence which we see in the vast majority of bisyllabic verbs. Lexically marking all these verbs for their association with a tone melody overshoots the mark. In addition, Their model cannot account for the fact that the penultimate syllables in piská 'fish' and komprendé, which are bimoraic, hence inherently prominent, fail to attract further marks of prominence. Prominence of a final light syllable is actually irregular for nouns such as piská 'fish', but perfectly regular for verbs such as komprendé 'to understand'. Devonish \& Murray treat piská 'fish' as regular, requiring no lexical tone information. In contrast, in their treatment, kompren$d e ́$ 'to understand' requires a lexically specified melody, because the antepenultimate syllable /koN/, which carries secondary stress, surfaces with a fall - something which is best considered a purely phonetic fact.

In sum, failure to distinguish between regular and irregular cases results in a model which treats some perfectly regular forms as lexical exceptions, and some irregular cases as if they were predictable.

\section{Tone as a marker of word class}

What emerges from the preceding is the need for an approach to Pp tone and stress which is capable of distinguishing between regular and irregular forms, in contrast with previous treatments.

Furthermore, the facts set out above suggest a departure from the assumption of previous work that $\mathrm{Pp}$ tone is a purely phonological property. The contrast between verbs and all other content words clearly shows that the location of a high tone provides a phonological clue for word class. The regular verb pattern aligns a high tone with the right edge of the verb, irrespective of the length of the verb. This can be expressed in the requirement that $\mathrm{Pp}$ verbs are matched against the template in (1).

(1)

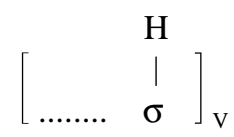

For other words (nouns, adjectives and adverbs), a simple quantity-sensitive algorithm predicts the location of a high tone and stress. Devonish $\&$ Murray's prominence attraction rings true here, with a high tone and stress 
naturally attracted to a heavy word-final syllable, i.e. to a syllable which meets the configuration in (2).

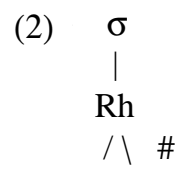

This can be effected by foot construction, which proceeds from the right edge, and assigns foot status to a heavy word-final syllable, which will then surface with a high tone and main stress. Where this configuration is not met, foot construction builds trochaic feet, thus assigning default head status to the penultimate syllable. A high tone and stress thus appear on that penultimate syllable by default. Just as a high tone on a final light syllable identifies a verb, quantity-sensitive high tone placement identifies non-verbal status.

More than one foot may be constructed on nouns or adjectives of sufficient length. Such words optionally surface with high tones on alternating syllables. This shows that high tones are assigned to the heads of adjacent feet.

\section{Stress placement in verbs}

Bisyllabic verbs and longer verbs part company where stress placement is concerned, which in bisyllabic verbs is penultimate, in trisyllabic and longer verbs is final. To begin with the latter, these verbs conform to the Pp preference for the cooccurrence of a high tone and stress. This preference can be seen not only in the predominant cooccurrence of high tone and stress in regular cases, but also in the fact that those nouns and adjectives which have an (irregular) high tone on a final, light syllable, usually combine it with stress on that syllable, rather than regularly assigning stress to the penultimate syllable (recall piská 'fish'). The participle form of verbs, including bisyllabic verbs, similarly combines a high tone with stress on a final, light syllable (recall matá 'killed' < mata 'to kill'), whereas the imperative of bisyllabic verbs combines stress and high tone on the penultimate syllable ( $m \bar{a} t \underline{t a}$ 'kill!').

Thus, verbs of three or more syllables length, with their cooccurrence of stress and a high tone on a final light syllable, can be seen to implement a more general requirement that foot construction assign head status to any high-toned syllable:

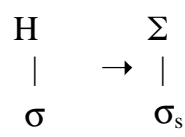


Thus, the assignment of stress in verbs of three or more syllables is posited tofollow from the presence of $\mathrm{H}$ tone on the final syllable, which itself followed from the requirement in (1).

The non-cooccurrence of high tone and stress in bisyllabic verbs can be considered the result of footing: verbs such as bula 'to jump', while conforming to (1), cannot also conform to (2), as it would result in the construction of a defective (because monomoraic) foot. The construction of a trochaic foot over the two syllables of such a verb, resulting in the representation in (4), allows conformation to the minimal word requirement (see footnote 2).

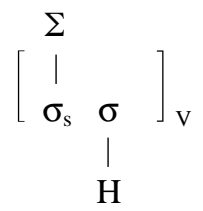

\section{Irregular tone and stress placement}

We noted earlier that a small number of bisyllabic nouns (mango 'mango' etc.) combine regular penultimate stress with an irregularly placed final high tone, like bisyllabic verbs. The lexical representations of these forms may be assumed to contain a pre-associated high tone. The non-cooccurrence of stress and a high tone in these irregular nouns is derived simply by foot construction - as is the case for the bisyllabic verbs which present this prosody.

The other irregular patterns of prominence in nouns, adjectives and adverbs, in each case, have both high tone and stress carried by an unexpected syllable. Like the mango-type irregularity, these require a pre-associated $\mathrm{H}$, either on a final light syllable which is treated as prominent (piská 'fish', etc.), on an antepenultimate syllable which is treated as prominent (ágila 'eagle', etc.), or on a penultimate syllable where a final heavy syllable is bypassed (difisil 'difficult', etc.). Foot construction, which assigns head position to a high-toned syllable, results in stress assignment to that syllable.

For all these forms, representations such as those in (5) are assumed, where a pre-associated high tone makes the representations more complex than is the case for words with a predictably located high tone. Thus, regular and irregular forms are clearly distinct underlyingly.

(5)<smiles>[13CH3][13CH2][13CH3]</smiles>

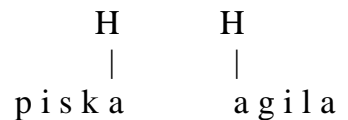<smiles>[AlH2][AlH2]</smiles>

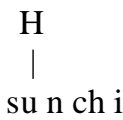
su n ch i

Finally, high tones on adjacent syllables, as in bistek 'steak', harspèl 'hairclip', can best be accounted for synchronically by assigning phonological 
word status to both parts, even if these are not morphologically independent. Compound stress is then assigned to the righthand member.

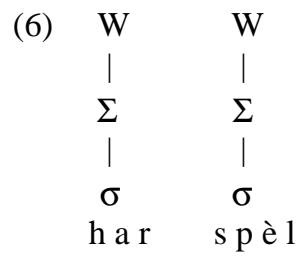

\section{Tone and stress placement in derived environments}

The preceding account of Pp tone and stress is based on a study of underived lexical items, but can be extended to account for tone and stress in derived contexts.

I will first consider non-affixal morphology, summarizing from Kouwenberg (1995). Non-affixal morphological processes effect a semantic and/or categorial change either by null conversion, or by a phonological change which affects tone and/or stress placement only, i.e. without causing a change in the segmental string. Consider, for instance, the forms which are relatable to peña 'to comb' in Table 6 .

Table 6. Derivation from input peña 'to comb'

\begin{tabular}{|l|l|l|}
\hline form & prosody & morphological status \\
\hline peñā 'to comb' & $\begin{array}{l}\text { penultimate stress, LH melody } \\
\text { (regular for bisyllabic verbs) }\end{array}$ & underived \\
\hline pēña 'comb' & $\begin{array}{l}\text { penultimate stress, HL melody } \\
\text { (regular for nouns) }\end{array}$ & $\begin{array}{l}\text { deverbal instrument } \\
\text { noun }\end{array}$ \\
\hline peñă 'combed' & $\begin{array}{l}\text { final stress, LH melody } \\
\text { (irregular stress for bisyllabic } \\
\text { verbs) }\end{array}$ & participle \\
\hline peñaa 'hairstyle' & $\begin{array}{l}\text { final stress, LH melody } \\
\text { (irregular for nouns) }\end{array}$ & deverbal result noun \\
\hline pẽña! 'comb!' & $\begin{array}{l}\text { penultimate stress, HL melody } \\
\text { (irregular melody for bisyllabic } \\
\text { verbs) }\end{array}$ & imperative \\
\hline
\end{tabular}

The tone and stress pattern of the deverbal instrument noun peña 'comb' does not require any particular account, since it constitutes the regular noun 
pattern, which will emerge from the application of default stress and high tone assignment to the penultimate syllable of a noun which ends in a light syllable. In other words, the morphological relation between peña 'to comb' and peña 'comb' actually constitutes a case of null conversion. Of the 250 bisyllabic vowel-final verb / noun pairs in Joubert (1991), roughly 110 are relatable in this way as verb / deverbal noun, with different semantic effects.

The participle peñá 'combed' (final stress) displays stress shift, as compared to the underived form peña 'to comb' (penultimate stress). This is representative of the formation of the participle of bisyllabic verbs with $\mathrm{LH}$ melody. Where the verb is longer, the base too has final stress, and no change is involved in the derivation of a participle form, as for instance in ataká 'to attack / attacked'. Where the base is bisyllabic but carries an irregular melody, the participle is formed by prefixation (see below).

It is clear that although participles such as peña 'combed' match the template in (1), they fail to match that in (4). In other words, in the formation of the participle form, the high-toned syllable is treated as a heavy syllable, capable of heading a foot, hence the recipient of stress. The template in (4), therefore, characterizes underived bisyllabic verbs only.

The deverbal noun peñá 'hairstyle' is identical in phonological form to the participle. The number of deverbal nouns which can thus be formed from a bisyllabic verb base is fairly small, and can best be accounted for as derived from the participle by conversion, rather than from the base verb, as also seen in the fact that these deverbal nouns often carry an interpretation which is associated with the completion or result of an event, e.g. habri' 'opening' < habri 'to open', huñá 'scratch' < huña 'to scratch'. The prosodic structure of the participle is maintained in this conversion, resulting in a tone and stress pattern which is irregular for nouns.

Some trisyllabic verbs also have related nouns which are distinguishable only by stress shift, in these cases from (regular) final stress on the verb to (regular) penultimate stress on the noun. This is true, for instance, of the relation between the verb vakuná 'to vaccinate' and the deverbal noun vakuna 'vaccination'. It is more usual, however, that a difference in the final vowel accompanies the different stress placement, as can be seen, for instance, in the pair venená 'to poison' - venenu 'poison'. The verb - noun pairs thus reflect the idiosyncratic properties of their etymological sources. In any case, the stress placement which we see in these cases is as expected for Pp verbs and nouns. As was the case for the morphological relation between peña 'to comb' and peña 'comb', again, no process of stress shift needs to be assumed.

Turning to affixal morphology, I will limit the discussion to those derivations which emerge from Dijkhoff's (1993) comprehensive overview as the most productive, including several which have extended their application to bases which their etymological source forms do not accept. In respect of tone and stress placement, three types of affixes may be distinguished: 
(i) Affixes which create a form that behaves as an underived form with respect to tone and stress placement. Most productive affixes fall into this category. Included are verbal prefixes which, where prefixed to a bisyllabic verb, create a trisyllabic verb; such derived verbs receive the tone and stress pattern approprite to a verb of that length, as seen in rebendé 'to retail', with final prominence (cf. bende 'to sell'). Similarly, there are suffixes which create derived nouns and adjectives which are treated as underived forms, as seen in stimashon 'love', with final prominence, and stimamentu '(the act of) loving', with penultimate prominence, both < stima 'to love'. Similarly, falsedat 'meanness', with final prominence, < falsu 'mean', and kurabel 'curable', with penultimate prominence ${ }^{6},<k u r a$ 'to heal, cure'. Finally, the formation of a gerundive form involves suffixation of -ndo to a vowel-final verb base, with tone and stress placement in the resultant form providing an indication of the non-verbal, noun-like character of the gerundive, as in kanando 'walking', with penultimate prominence, < kana 'to walk'.

(ii) One affix does not affect the tone and stress of its base, viz. the prefix $h e-\sim e$ - or $d i-\sim i$ - which forms the participle of monosyllabic verbs and of bisyllabic verbs with an irregular tone melody. Where trisyllabic forms are thus created, the (irregular) tone and stress placement of the base are maintained. Thus, hewèlder 'welded' (penultimate $\mathrm{H}$ and stress) < wèlder 'to weld' (ditto). Apparently, the pre-associated high tone of the irregular verb stem is not erased by the application of morphological processes. Nor does prefixation to a monosyllabic verb base have any effect on its melody. Thus, hedal 'hit', hechèk 'checked, verified', hedrei 'turned (around)', all with H and stress on the verb stem, < dal 'to hit', chèk 'to check, verify', drei 'to turn (around)'. All this suggests that the prefixed participle is formed after prosodic structure has been built. This may indicate that the "prefix" constitutes a clitic rather than an affix.

(iii) The suffix - dó can be considered auto-stressed, or - more accurately "auto-toned", i.e. pre-associated with a high tone. It thus also attracts main stress, hence ganadó 'winner' (final H and stress) < gana 'to win'.

An analysis of the placement of Pp tone as determined by word class, can be succesfully extended to derived environments, as seen in the preceding. As in underived lexical items, most complex forms surface with the tone and stress which is expected from words of a particular class, with a minority of forms requiring a pre-associated high tone to account for their irregular prosody.

\footnotetext{
${ }^{6}$ The suffix - bel contains /l/ only in a monomoraic rhyme, as seen in its phonetic form [bəl]. It is treated, therefore, as a light syllable. As expected, in words which end in this suffix, prominence is assigned to the penultimate syllable.
} 


\section{Conclusion}

Treating tone as a phonological marker of word category allows for a straightforward account of Pp tone placement. Regular tone placement thus turns out to be predictable from a combination of categorial and prosodic information. Irregular tone placement is clearly distinguishable from the regular patterns in this approach.

\section{References}

Devonish, H., \& Murray, E. (1995). On stress and tone in Papiamentu: an alternative analysis. Uwiling. Working papers in linguistics (Department of Language and Linguistics, University of the West Indies, Mona), 1, 43-57.

Dijkhoff, M. (1993). Papiamentu word formation. University of Amsterdam Ph.D Dissertation.

Joubert, S.M. (1991). Dikshonario Papiamentu-Hulandes. Curaçao: Fundashon di Leksikografia.

Kouwenberg, S. (1995). Conversion in disguise: observations on Papiamentu non-affixal morphology. Uwiling. Working papers in linguistics (Department of Language and Linguistics, University of the West Indies, Mona), 1, 13-30.

Kouwenberg, S., \& Murray, E. (1994). Papiamentu (Languages of the world/Materials 68). München: Lincom Europa.

Rivera-Castillo, Y. (1998). Tone and stress in Papiamentu: The contribution of a constraint-based analysis to the problem of creole genesis. Journal of Pidgin and Creole Languages, 13, 297-334.

Römer, R.G. (1977). Polarization phenomena in Papiamentu [reprinted in Römer 1991]. Amsterdam Creole Studies I, 69-79.

(1983). Papiamentu tones. In E. Muller (Ed.), Papiamentu: Problems and possibilities. Zutphen: De Walburg Pers.

(1991). Studies in Papiamentu tonology (Caribbean Culture Studies 5). Amsterdam \& Kingston: University of Amsterdam \& University of the West Indies.

Department of Language, Linguistics \& Philosophy University of the West Indies, Jamaica silvia.kouwenberg@uwimona.edu.jm 